\title{
Wymagania dotyczące ewidencji i sprawozdawczości w zakresie emisji do powietrza zanieczyszczeń towarzyszących eksploatacji złóż ropy naftowej i gazu ziemnego
}

\begin{abstract}
W artykule omówiono przepisy prawne regulujące prowadzenie przez podmioty korzystające ze środowiska ewidencji i sprawozdawczości w zakresie emisji gazów lub pyłów do powietrza oraz ponoszenie z tego tytułu należnych opłat. Zaprezentowano zmiany, jakie wejdą w życie w 2017 r., a których celem jest ujednolicenie systemu sprawozdawczości i systemu opłat. Przedstawiono główne procesy i źródła wprowadzanych do powietrza zanieczyszczeń, do raportowania których zobowiązane są podmioty prowadzące eksploatację złóż węglowodorów.
\end{abstract}

Słowa kluczowe: sprawozdawczość środowiskowa, emisja zanieczyszczeń, emitory.

\section{Requirements concerning recording and reporting of emissions into the atmosphere of impurities associated with the exploitation of oil and natural gas}

\begin{abstract}
The article discusses the legal provisions governing the conduct by users of the environment accounting and reporting of greenhouse gases or dust into the air, and the required fees. The changes to be introduced in 2017, aimed at harmonizing the process of reporting the system of charging, are presented. Also presented are the main processes and sources of impurities released into the air, the reporting of which are obliged, operators conducting the exploitation of coal and hydrocarbons.
\end{abstract}

Key words: environmental reporting, emissions, pollution emitters.

\section{Wstęp}

Przepisy prawa ochrony środowiska nakładają na przedsiębiorstwa obowiązek samodzielnego naliczania wysokości opłat z tytułu korzystania ze środowiska (w tym za wprowadzanie gazów lub pyłów do powietrza), a także do prowadzenia $\mathrm{w}$ tym zakresie odpowiedniej ewidencji i sprawozdawczości. Aby wartość należnej opłaty można było uznać za prawidłową, muszą zostać spełnione dwa warunki:

- wielkości emisji muszą być poprawnie obliczone,

- prawidłowo muszą zostać przyjęte stawki opłat.

Generalnie przepisy nie określają sposobu ustalania rocznej wielkości emisji na potrzeby systemu opłat (za wyjątkiem instalacji objętych wspólnotowym systemem handlu uprawnieniami do emisji EU ETS w zakresie $\mathrm{CO}_{2}$ ). Korzy- stający ze środowiska, wprowadzający gazy lub pyły do powietrza, zobowiązany jest płacić za „wszystkie” emitowane zanieczyszczenia.

Możliwość określenia sposobów ustalania wielkości emisji dla poszczególnych rodzajów instalacji daje art. 7 ust. 4 Ustawy z dnia 17 lipca 2009 r. o systemie zarzadzania emisjami gazów cieplarnianych i innych substancji (Dz. U. z 2015 r., poz. 2273, z późn. zm.) stanowiący delegację dla Ministra Środowiska do określenia, w drodze rozporządzenia, takich sposobów. Jak dotąd rozporządzenie takie nie zostało wydane.

Obliczenia wielkości emisji powinny obejmować wszystkie rodzaje substancji wprowadzanych do powietrza oraz wszystkie źródła emisji eksploatowane przez prowadzącego 
instalację. Powinny również wykorzystywać najlepszą spośród dostępnych metod obliczeniowych, tj.:

- metodę opartą na wynikach pomiarów ciągłych,

- metodę opartą na wynikach pomiarów okresowych, bilansach lub wskaźnikach ogólnych o wysokiej pewności (dotyczy głównie wskaźników emisji ditlenku węgla),

- dane literaturowe (wskaźniki literaturowe) [8].

Każdego roku podmioty gospodarcze zobowiązane są do składania raportów (sprawozdań) z zakresu korzystania ze środowiska. Należą do nich m.in.:

- opłaty za korzystanie ze środowiska - czyli wykaz zawierający zbiorcze zestawienie informacji na temat korzystania ze środowiska wraz z wyliczeniem należnych opłat za ilości gazów lub pyłów wprowadzanych do powietrza, przekazywany do marszałka województwa,

- raport do bazy Krajowego Ośrodka Bilansowania i Zarządzania Emisjami (KOBiZE), zawierający informacje o emisji do powietrza gazów cieplarnianych i innych substancji oraz prowadzonej działalności, na skutek której występuje emisja,

- sprawozdania do Głównego Urzędu Statystycznego - raportowanie oraz uzupełnianie bazy sprawozdawczej GUS,

- sprawozdanie do Europejskiego Rejestru Uwalniania i Transferu Zanieczyszczeń (PRTR) o ilości i rodzajach uwalnianych lub transferowanych poza instalację zanieczyszczeń (odpadów, ścieków, emisji do powietrza) [8].

\section{Wymagania prawne dotyczące ewidencji i sprawozdawczości w zakresie emisji zanieczyszczeń do powietrza}

Podmioty korzystające ze środowiska w rozumieniu art. 3 pkt 20 Ustawy z dnia 27 kwietnia $2001 \mathrm{r}$. Prawo ochrony środowiska (POŚ, Dz. U z 2016 r., poz. 672) zobowiązane są do wnoszenia opłat z tytułu wprowadzania gazów lub pyłów do powietrza. Opłaty te ponoszone są zarówno w związku z pozwoleniem na wprowadzanie gazów i pyłów do środowiska (w tym pozwoleniem zintegrowanym), jak i w przypadku, gdy gazy i pyły trafiają do powietrza z urządzeń, dla których nie jest wymagane pozwolenie na emisję gazów i pyłów do powietrza oraz pozwolenie zintegrowane. Opłaty ustala się według stawek obowiązujących w okresie, w którym korzystanie ze środowiska miało miejsce [3].

Sposób wnoszenia opłat (w tym wzory wykazów zawierających informacje o ilości i rodzajach gazów lub pyłów wprowadzanych do powietrza), dane na podstawie których określono te ilości, a także stawki opłat regulują rozporządzenia szczegółowe:

- Rozporzadzenie Ministra Środowiska z dnia 27 lutego 2014 r. w sprawie wykazów zawierajacych informacje $i$ dane o zakresie korzystania ze środowiska oraz o wysokości należnych opłat (Dz. U. z 2014 r., poz. 274),

- Rozporzadzenie Rady Ministrów z dnia 12 października 2015 r. w sprawie oplat za korzystanie ze środowiska (Dz. U. z 2015 r., poz. 1875),

a także obwieszczenia w sprawie wysokości stawek opłat za korzystanie ze środowiska wydawane na każdy kolejny rok kalendarzowy.

Zgodnie z art. 274 ust. 1 pkt 1 ustawy POŚ, podmioty korzystające ze środowiska ponoszą opłatę za wprowadzanie do powietrza gazów lub pyłów w wysokości uzależnionej od ilości i rodzaju gazów lub pyłów emitowanych do powietrza. Opłatę ustala się na podstawie wielkości rzeczywistej emisji oraz obowiązujących w danym roku jednostko- wych stawek opłat za gazy lub pyły wprowadzane do powietrza. Podmiot korzystający ze środowiska jest zobowiązany określić we własnym zakresie wskaźniki emisji/unosu, a także ustaloną na ich podstawie wysokość należnej opłaty (art. 284 ustawy POŚ). W systemie opłat raportowanych jest 67 substancji (gazów lub pyłów) wymienionych w załączniku nr 1 do rozporządzenia w sprawie opłat.

W określonych przypadkach, gdy brak jest możliwości ustalenia poszczególnych rodzajów i ilości substancji wprowadzanych do powietrza, podmiot korzystający ze środowiska może posłużyć się zryczałtowanymi jednostkowymi stawkami opłat, ale dotyczy to tylko emisji substancji takich jak:

- powstające z przeładunku benzyn silnikowych,

- pochodzące z kotłów o nominalnej mocy cieplnej do $5 \mathrm{MW}$, opalanych węglem kamiennym, koksem, drewnem, olejem lub paliwem gazowym, dla których nie jest wymagane pozwolenie na wprowadzanie gazów lub pyłów do powietrza albo pozwolenie zintegrowane,

- pochodzące z procesów spalania paliw w silnikach spalinowych.

Opłata z tych źródeł naliczana jest na podstawie rzeczywistego zużycia paliwa i ilości przeładowanych benzyn silnikowych.

W obecnym stanie prawnym, z tytułu korzystania ze środowiska, obowiązuje roczny system wnoszenia opłat oraz składania sprawozdań (wykazów) zawierających informacje i dane wykorzystane do ustalenia wysokości opłat. Podmiot korzystający ze środowiska, zgodnie z art. 285 ust. 2 ustawy POŚ, jest zobowiązany wnieść opłatę za dany rok kalendarzowy do dnia 31 marca następnego roku.

Ponadto, w terminie do końca lutego każdego roku kalendarzowego, podmiot korzystający ze środowiska ma obo- 
wiązek sporządzić i wprowadzić do Krajowej bazy o emisjach gazów cieplarnianych i innych substancji, prowadzonej przez Krajowy Ośrodek Bilansowania i Zarządzania Emisjami (KOBiZE), roczny raport zawierający szczegółowe informacje o wielkości emisji do powietrza gazów cieplarnianych i innych substancji [4]. Ustawowy obowiązek raportowania danych o emisji gazów cieplarnianych do powietrza dotyczy każdego podmiotu korzystającego ze środowiska, w tym także nieposiadającego instalacji, a jedynie eksploatującego urządzenia (np. tylko środki transportu).

Obowiązek rejestracji w KOBiZE i raportowania narzuca art. 7 Ustawy z dnia 17 lipca 2009 r. o systemie zarzadzania emisjami gazów cieplarnianych i innych substancji (Dz. U. z 2015 r., poz. 2273).

Raport do KOBiZE powinien zawierać informacje o:

- wielkościach emisji substancji wprowadzanych do powie- trza (na podstawie prowadzonych pomiarów lub informacji o wielkości produkcji, zużyciu paliw lub surowców i odpowiadających tym wielkościom wskaźników emisji);

- wielkościach produkcji oraz charakterystyce surowców i paliw towarzyszących emisjom;

- środkach technicznych mających na celu zapobieganie lub ograniczanie emisji;

- wielkościach emisji zredukowanej i emisji unikniętej w wyniku realizacji przedsięwzięć oraz terminach osiągnięcia tych redukcji;

- planowanych terminach uruchomienia nowych przedsięwzięć oraz wielkości emisji substancji wprowadzanych do powietrza $z$ tych przedsięwzięć.

W przeciwieństwie do systemu „opłatowego” raport do KOBiZE obejmuje wyłącznie informacje dotyczące wprowadzania zanieczyszczeń do powietrza.

\section{Emitory}

Eksploatacji złóż węglowodorów (w tym procesom uzdatniania gazu ziemnego i ropy naftowej prowadzonym w celu nadania wydobytym surowcom odpowiednich parametrów produktów handlowych), a także operacjom i procesom po-

Tablica 1. Źródła emisji substancji do powietrza

\begin{tabular}{|c|c|c|c|}
\hline Lp. & Nazwa procesu & Emitory & Charakterystyka (paliwo/proces) \\
\hline \multirow{8}{*}{1.} & \multirow{8}{*}{$\begin{array}{l}\text { Energetyczne } \\
\text { spalanie paliw }\end{array}$} & kotły, piece gazowe & paliwo: gaz ziemny lub olej opałowy \\
\hline & & agregaty prądotwórcze & $\begin{array}{l}\text { paliwo: olej napędowy, gaz ziemny, benzyna - agregaty stacjo- } \\
\text { narne i przenośne }\end{array}$ \\
\hline & & podgrzewacze liniowe & paliwo: gaz ziemny \\
\hline & & wytwornice pary & paliwo: olej napędowy \\
\hline & & regeneratory glikolu & paliwo: gaz ziemny \\
\hline & & silniki gazowe (Waukesha) & $\begin{array}{l}\text { paliwo: gaz ziemny } \\
\text { stosowane do napędu sprężarek }\end{array}$ \\
\hline & & kompresory gazu / układy pompowe & paliwo: gaz ziemny \\
\hline & & pompy przeciwpożarowe & paliwo: olej napędowy \\
\hline \multirow{5}{*}{2.} & \multirow{5}{*}{$\begin{array}{l}\text { Procesy } \\
\text { technologiczne }\end{array}$} & dopalacze gazów kwaśnych i resztkowych & dopalanie gazów kwaśnych i gazów resztkowych \\
\hline & & pochodnie & $\begin{array}{l}\text { spalanie gazu ziemnego (zrzutowego) w pochodniach otwar- } \\
\text { tych lub zamkniętych }\end{array}$ \\
\hline & & emisje bez procesu spalania & $\begin{array}{l}\text { emisje gazu ziemnego podczas konserwacji i remontów (np. } \\
\text { wydmuchy podczas rozgazowania separatorów, rewizji we- } \\
\text { wnętrznej urządzeń ciśnieniowych itp.), awarii, syfonowania } \\
\text { otworów, z nieszczelności (rozszczelnienia pomp, zaworów) }\end{array}$ \\
\hline & & $\begin{array}{l}\text { zbiorniki ropy naftowej, kondensatu } \\
\text { (gazoliny), metanolu i LPG }\end{array}$ & $\begin{array}{l}\text { magazynowanie w zbiornikach ropy naftowej, kondensatu (ga- } \\
\text { zoliny), metanolu i LPG }\end{array}$ \\
\hline & & stanowiska nalewcze & $\begin{array}{l}\text { operacje przeładunku ropy naftowej, kondensatu (gazoliny), } \\
\text { metanolu i LPG }\end{array}$ \\
\hline \multirow{3}{*}{3.} & \multirow{3}{*}{$\begin{array}{l}\text { Operacje } \\
\text { pomocnicze }\end{array}$} & spawanie & spawanie przy użyciu elektrod oraz drutów elektrodowych \\
\hline & & malowanie & $\begin{array}{l}\text { malowanie farbami oraz stosowanie rozpuszczalników orga- } \\
\text { nicznych }\end{array}$ \\
\hline & & spalanie paliw w środkach transportu & spalanie paliw silnikowych \\
\hline
\end{tabular}


mocniczym towarzyszą emisje gazów i pyłów do powietrza. Zanieczyszczenia te przedostają się do powietrza w sposób zorganizowany i niezorganizowany.

Z emisją zorganizowaną mamy do czynienia w przypadku, gdy zanieczyszczenia do powietrza z wszelkiego rodzaju procesów technologicznych i procesów spalania wprowadzane są za pośrednictwem emitorów punktowych, stacjonarnych, tj. kominów, wylotów wentylacyjnych itp.

Emisja niezorganizowana ma miejsce w przypadku wprowadzania do powietrza zanieczyszczeń bez pośrednictwa przeznaczonych do tego celu środków technicznych, np. z operacji przeładunku i magazynowania ropy naftowej oraz gazu LPG. Towarzyszy ona pracom pomocniczym, takim jak malowanie i spawanie. Jako emisję niezorganizowaną traktuje się także emisję zanieczyszczeń gazowych i pyłu pochodzącą ze spalania gazu ziemnego w pochodniach gazu zrzutowego (tzw. flarach), w których poprzez spalenie unieszkodliwia się gaz ziemny pochodzący m.in. ze zrzutów z awaryjnych zaworów wydmuchowych, zaworów bezpieczeństwa, opróżniania instalacji podczas remontów, a także niewykorzystywany gaz ziemny towarzyszący ropie naftowej.
Źródłami emisji gazów i pyłów do powietrza w obiektach prowadzących wydobywanie oraz uzdatnianie ropy naftowe i gazu ziemnego są procesy:

- energetycznego spalania paliw (gazu ziemnego, oleju opałowego, oleju napędowego, gazu płynnego, benzyny) prowadzone w celu pozyskania energii elektrycznej i cieplnej,

- technologiczne, w tym inne niż energetyczne spalanie paliw, takie jak:

- spalanie gazu ziemnego (zrzutowego) w pochodni,

- dopalanie gazów kwaśnych,

- magazynowanie (ropy naftowej, metanolu, LPG),

- przeładunek (ropy naftowej, metanolu, LPG),

- nieszczelności, upusty z instalacji,

- pomocnicze, takie jak:

- spawanie,

- malowanie,

- spalanie paliw w środkach transportu.

Tablica 1 przedstawia procesy, którym towarzyszy wprowadzanie zanieczyszczeń gazowych i pyłowych do powietrza.

\section{Rodzaje zanieczyszczeń emitowanych do powietrza}

Głównymi zanieczyszczeniami emitowanymi do powietrza, które podlegają sprawozdawczości w związku z opłatami za korzystanie ze środowiska (a także do KOBiZE), są: $\mathrm{CO}_{2}, \mathrm{SO}_{2}, \mathrm{NO}_{\mathrm{x}}, \mathrm{CO}, \mathrm{CH}_{4}$, lotne związki organiczne (LZO), pyły, węglowodory, alkohole i metale ciężkie.

Wśród wszystkich wprowadzanych do powietrza zanieczyszczeń największy udział ma emisja ditlenku węgla pochodząca z procesów spalania paliw w źródłach ciepła i technologicznych. Procesy spalania paliw są ponadto odpowiedzialne za emisję do powietrza znacznej ilości ditlenku siarki, tlenku węgla oraz tlenków azotu (w przeliczeniu na $\mathrm{NO}_{2}$ ) i pyłu. Paliwem najczęściej stosowanym w urządzeniach cieplnych i technologicznych jest gaz ziemny wysokometanowy oraz zaazotowany, ponadto używa się oleju opałowego i napędowego, a także gazu płynnego LPG oraz - w nielicznych przypadkach - benzyny $[1,5,7]$.

Procesami spalania prowadzonymi podczas eksploatacji złóż ropy naftowej i gazu ziemnego są m.in.:

- energetyczne spalanie paliw w celu wytworzenia energii:

- cieplnej (na potrzeby technologiczne i socjalno-bytowe) - kotły technologiczne, piece gazowe, wytwornice pary, podgrzewacze gazu i oleju grzewczego, regeneratory glikolu, kotły użytkowe (c.o. i c.w.u.) - opalane gazem ziemnym, olejem opałowym, olejem napędowym,

- elektrycznej - agregaty prądotwórcze z silnikami gazowymi, olejowymi, benzynowymi,
- mechanicznej - kompresory, agregaty pompowe, - pozaenergetyczne spalanie (technologiczne):

- gazu ziemnego w pochodniach gazu zrzutowego,

- gazów resztkowych z instalacji odsiarczania gazu ziemnego (dopalacze gazów kwaśnych) oraz z odgazowania ropy naftowej, np. na ekspedytach ropy naftowej.

Produktami spalania paliw są spaliny zawierające ditlenek węgla, ditlenek siarki, tlenek węgla, tlenki azotu, pyły i popiół lotny, a także węglowodory (alifatyczne i aromatyczne), które nie uległy spaleniu. Źródłem emisji zanieczyszczeń do powietrza są ponadto procesy technologiczne niezwiązane ze spalaniem paliw. Należą do nich operacje: magazynowania i manipulacji produktami, tj. ropa naftową, kondensatem (gazoliną), gazem płynnym propan-butan (LPG), siarką płynną oraz metanolem. Potencjalnym źródłem emisji składników gazu ziemnego do powietrza mogą być ponadto zbiorniki magazynowe wody złożowej $[1,6,10]$.

W celu ograniczenia emisji do atmosfery szkodliwego siarkowodoru, w jednostkach prowadzących procesy odsiarczania gazu ziemnego stosuje się unieszkodliwianie gazów resztkowych z instalacji Claus'a poprzez ich spalenie w tzw. dopalaczach gazów kwaśnych. Do atmosfery wprowadzany jest wówczas mniej szkodliwy ditlenek siarki.

Dużej części tych emisji (węglowodorów alifatycznych, aromatycznych, siarkowodoru) można uniknąć lub znacz- 
Tablica 2. Przykładowe źródła emitowanych substancji

\begin{tabular}{|c|c|c|c|}
\hline Lp. & Nazwa substancji & Rodzaj źródła emisji z urządzenia & Nazwa procesu \\
\hline \multirow[b]{2}{*}{1.} & \multirow[b]{2}{*}{ Ditlenek węgla $\left(\mathrm{CO}_{2}\right)$} & $\begin{array}{l}\text { kotły, agregaty prądotwórcze, piece, podgrzewacze, regeneratory, } \\
\text { pompy, wytwornice pary }\end{array}$ & energetyczne spalanie paliw \\
\hline & & $\begin{array}{l}\text { pochodnie, dopalacze gazów kwaśnych, z nieszczelności: rozszczel- } \\
\text { nienia, upusty, przedmuchy instalacji, zrzut gazu z zestawów tłocz- } \\
\text { nych, odgazowanie, wydmuchy z zaworów bezpieczeństwa itd. }\end{array}$ & technologiczny \\
\hline 2. & $\operatorname{Metan}\left(\mathrm{CH}_{4}\right)$ & $\begin{array}{l}\text { nieszczelności: z zaworów, łączenia rur, przyłącza urządzeń, roz- } \\
\text { szczelnienia, upusty, przedmuchy instalacji, zrzut gazu z zestawów } \\
\text { tłocznych, odgazowanie, wydmuchy z zaworów bezpieczeństwa itd. }\end{array}$ & technologiczny \\
\hline \multirow{3}{*}{3.} & \multirow{3}{*}{ Tlenki azotu $\left(\mathrm{NO}_{\mathrm{x}} / \mathrm{NO}_{2}\right)$} & $\begin{array}{l}\text { kotły, agregaty prądotwórcze, piece, podgrzewacze, regeneratory, } \\
\text { pompy, wytwornice pary }\end{array}$ & energetyczne spalanie paliw \\
\hline & & pochodnie, dopalacze gazów kwaśnych & technologiczny \\
\hline & & spawanie & pomocniczy \\
\hline \multirow[t]{2}{*}{4.} & \multirow[t]{2}{*}{ Ditlenek siarki $\left(\mathrm{SO}_{2}\right)$} & $\begin{array}{l}\text { kotły, agregaty prądotwórcze, piece, podgrzewacze, regeneratory, } \\
\text { pompy, silniki gazowe Waukesha (do napędu sprężarek tłokowych), } \\
\text { wytwornice pary }\end{array}$ & energetyczne spalanie paliw \\
\hline & & pochodnie, dopalacze gazów kwaśnych & technologiczny \\
\hline \multirow{3}{*}{5.} & \multirow{3}{*}{ Tlenek węgla $(\mathrm{CO})$} & $\begin{array}{l}\text { kotły, agregaty prądotwórcze, piece, podgrzewacze, regeneratory, } \\
\text { pompy, silniki gazowe Waukesha (do napędu sprężarek tłokowych), } \\
\text { wytwornice pary }\end{array}$ & energetyczne spalanie paliw \\
\hline & & pochodnie, dopalacze gazów kwaśnych & technologiczny \\
\hline & & spawanie & pomocniczy \\
\hline \multirow[t]{2}{*}{6.} & \multirow{2}{*}{$\begin{array}{l}\text { Pył zawieszony całko- } \\
\text { wity (TSP) }\end{array}$} & $\begin{array}{l}\text { kotły, regeneratory, piece, podgrzewacze, silniki gazowe Waukesha } \\
\text { (do napędu sprężarek tłokowych) }\end{array}$ & energetyczne spalanie paliw \\
\hline & & pochodnie, dopalacze gazów kwaśnych & technologiczny \\
\hline 7. & Pozostałe pyły & spawanie & pomocniczy \\
\hline \multirow{3}{*}{8.} & \multirow{3}{*}{$\begin{array}{l}\text { Węglowodory alifa- } \\
\text { tyczne }\end{array}$} & agregaty prądotwórcze, pompy, wytwornice pary & energetyczne spalanie paliw \\
\hline & & zbiorniki magazynowe ropy naftowej, stanowiska nalewcze & technologiczny \\
\hline & & $\begin{array}{l}\text { dopalacze gazów kwaśnych, z nieszczelności: rozszczelnienia, upu- } \\
\text { sty, przedmuchy instalacji, zrzut gazu z zestawów tłocznych, odga- } \\
\text { zowanie, wydmuchy z zaworów bezpieczeństwa itd. }\end{array}$ & pomocniczy \\
\hline \multirow{2}{*}{9.} & \multirow{2}{*}{$\begin{array}{l}\text { Węglowodory aroma- } \\
\text { tyczne (WWA) }\end{array}$} & agregaty prądotwórcze, pompy, wytwornice pary & energetyczne spalanie paliw \\
\hline & & malowanie & pomocniczy \\
\hline 10. & $\begin{array}{l}\text { Lotne związki organicz- } \\
\text { ne (LZO) }\end{array}$ & malowanie & pomocniczy \\
\hline
\end{tabular}

nie je ograniczyć dzięki zastosowaniu rozwiązań technicznych polegających na wykorzystaniu systemów odgazowu- jących, których zadaniem jest zebranie oparów i skierowanie na urządzenia spalające/dopalające.

\section{Podsumowanie}

Aktualnie raporty do KOBiZE oraz wykazy wielkości emisji zanieczyszczeń wprowadzanych do powietrza, będące podstawą do wnoszenia opłat z tytułu korzystania ze środowiska, funkcjonują niezależnie od siebie i nie są objęte spójnym systemem.

W związku z mającymi nastąpić od 2017 r. zmianami, zgodnie z art. 285 znowelizowanej ustawy POŚ, podmioty korzystające ze środowiska będą wnosić opłaty za wprowadzanie gazów lub pyłów do powietrza w wysokości ustalonej na podstawie wielkości rocznej emisji określonej w raporcie składanym do Krajowej bazy o emisjach gazów cieplarnianych i innych substancji (prowadzonej przez KOBiZE). Docelowo coroczny raport KOBiZE o emisjach gazów cieplarnianych i innych substancji ma zastąpić dotychczaso- 
wą sprawozdawczość związaną z opłatami za gazy lub pyły wprowadzane do powietrza. Celem tych zmian jest zapewnienie spójności w raportowaniu emisji.

Dane przekazywane do Krajowej bazy będą stanowić podstawę do opracowania raportów wymaganych na potrzeby systemu opłat za wprowadzanie gazów lub pyłów do powietrza, statystyki publicznej, sprawozdawczości w ramach systemu handlu uprawnieniami do emisji gazów cieplarnianych w Unii Europejskiej, systemu bilansowania i rozliczania wielkości emisji ditlenku siarki $\left(\mathrm{SO}_{2}\right)$ i tlenków azotu $\left(\mathrm{NO}_{\mathrm{x}}\right)$ dla dużych źródeł spalania. Stworzenie jednego spójnego systemu ma zapewnić jednolitość danych przekazywanych do poszczególnych systemów. Gromadzenie informacji w jednym miejscu pozwoli na dokonywanie porównań i weryfikację danych emisyjnych, a także ograniczy do minimum sprawozdawczość nałożoną na podmioty korzystające ze środowiska oraz organy administracji samorządowej i rządowej.

Planowana jest ponadto docelowo budowa systemu ewidencji opłat, jednolitego w skali kraju i wspólnego dla poszczególnych komponentów środowiska, który będzie wykorzystywany przez wszystkie urzędy marszałkowskie. Zostanie on połączony z Krajową bazą o emisjach gazów cieplarnianych i innych substancji oraz bazami zawierającymi dane zbierane w zakresie poszczególnych komponentów środowiska.

Prosimy cytować jako: Nafta-Gaz 2016, nr 10, s. 851-856, DOI: 10.18668/NG.2016.10.10

Artykuł nadesłano do Redakcji 8.08.2016 r. Zatwierdzono do druku 7.10.2016 r.

Artykuł powstał na podstawie pracy statutowej pt. Opracowanie metodologii obliczania wielkości emisji zanieczyszczeń do powietrza z instalacji energetycznego i nieenergetycznego spalania paliw towarzyszacych eksploatacji złóż ropy naftowej $i$ gazu ziemnego - praca INiG - PIB na zlecenie MNiSW; nr zlecenia: 0017/SN/16, nr archiwalny: DK-4100-0017/16.

\section{Literatura}

[1] EMEP/EEA Air Pollutant Emission Inventory Guidebook 2013, Oil - Exploration, production, transport, Technical guidance to prepare national emission inventories, 2013.

[2] Krajowy Ośrodek Bilansowania i Zarządzania Emisjami (KOBiZE); Poradnik dotyczacy sporządzenia i wprowadzenia raportu do Krajowej bazy za lata 2014-2015, 2016.

[3] Krajowy Ośrodek Bilansowania i Zarządzania Emisjami (KOBiZE); Wybrane obowiazki sprawozdawcze wynikajace z przepisów prawa międzynarodowego, unijnego oraz krajowego w zakresie ochrony powietrza, 2011.

[4] Krajowy Ośrodek Bilansowania i Zarządzania Emisjami; http://www.kobize.pl/ (dostęp: 29.06.2016).

[5] Matusiak J.: Wpływ warunków materiałowych i technologicznych na emisję zanieczyszczeń przy spawaniu wysokostopowych stali nierdzewnych. Przegląd Spawalnictwa 2008, nr 8 , s. $3-11$.

[6] Ministerstwo Środowiska; Dokument Referencyjny BAT dla ogólnych zasad monitoringu - zintegrowane zapobieganie i ograniczanie zanieczyszczeń (IPPC), 2003.

[7] Paradysz R.: Monitoring lotnych zwiazków organicznych: Zdrowie, bezpieczeństwo i zadbane środowisko. Rynek Polskiej Nafty i Gazu 2014, nr 9, s. 50-51.

[8] Portal internetowy „Wszystko o emisjach”; http://wszystkooemisjach.pl/ (dostęp: 30.06.2016).

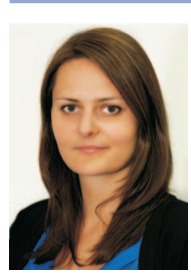

Mgr Joanna NIEMCZEWSKA

Asystent w Zakładzie Ocen Środowiskowych. Instytut Nafty i Gazu - Państwowy Instytut Badawczy ul. Lubicz 25 A

31-503 Kraków

E-mail: joanna.niemczewska@inig.pl
[9] Steczko K., Dobrzańska M.: Krajowe górnictwo naftowe i gazownictwo w obliczu współczesnych wyzwań ekologicznych i polityki ekologicznej Wspólnoty Europejskiej. Nafta-Gaz 2010, nr 12, s. 1115-1122.

[10] U.S. Environmental Protection Agency (US EPA); Emission Factor Documentation for AP-42 Section 1.4 Natural Gas Combustion, 1996.

\section{Akty prawne i normatywne}

[11] Obwieszczenie Ministra Środowiska z dnia 11 maja 2015 r. w sprawie wysokości górnych jednostkowych stawek opłat za korzystanie ze środowiska na rok 2016 (M. P. z 2015 r., poz. 815).

[12] Rozporzadzenie Ministra Środowiska z dnia 27 lutego 2014 r. w sprawie wykazów zawierajacych informacje $i$ dane o zakresie korzystania ze środowiska oraz o wysokości należnych opłat (Dz. U. z 2014 r., poz. 274).

[13] Rozporzadzenie Rady Ministrów z dnia 12 października 2015 r. w sprawie oplat za korzystanie ze środowiska (Dz. U. z 2015 r., poz. 1875).

[14] Ustawa z dnia 17 lipca 2009 r. o systemie zarzadzania emisjami gazów cieplarnianych i innych substancji (Dz. U. z 2015 r., poz. 2273).

[15] Ustawa z dnia 27 kwietnia 2001 r. Prawo ochrony środowiska (Dz. U. z 2016 r., poz. 672).

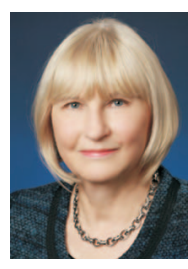

Mgr inż. Joanna ZALESKA-BARTOSZ

Starszy specjalista badawczo-techniczny w Zakładzie Ocen Środowiskowych.

Instytut Nafty i Gazu - Państwowy Instytut Badawczy ul. Lubicz 25 A

31-503 Kraków

E-mail: zaleska-bartosz@inig.pl 